Article

\title{
'Social Control' and the Politics of Public Participation in Water Remunicipalization, Cochabamba, Bolivia
}

\author{
Nasya S. Razavi \\ The City Institute, York University, Toronto, ON M3J 1P3, Canada; nsrazavi@yorku.ca
}

Received: 8 January 2019; Accepted: 9 July 2019; Published: 14 July 2019

check for

updates

\begin{abstract}
During the Water War in 2000, residents of Cochabamba, Bolivia, famously mobilized against water privatization and gained back public control of the city's water utility. Nearly two decades later, the water movement's vision of democratic water provision under the participatory management of 'social control' remains largely unfulfilled. This paper points to the difficulties in rebuilding a strong public water service in Cochabamba, focusing on the different-and often incompatible-understandings and interpretations of public participation. Addressing the concept's malleability to a spectrum of ideologies, this paper builds a typology of different kinds of participation according to their intentionality, outcomes, tools, and practices. Applying this framework to the water politics in Bolivia serves to untangle competing perspectives of participation, uncover whose interests are served, and which groups are included or excluded from access to water and decision-making. This analysis reveals how transformative participation has failed to take hold within the municipal service provider in Cochabamba.
\end{abstract}

Keywords: social control; participation; water governance; remunicipalization; Cochabamba; Bolivia

\section{Introduction}

The trend of water remunicipalization in several cities around the world demonstrates the enthusiasm for, and viability of, public alternatives for water service delivery $[1,2]$. The Water War of 2000 in Cochabamba, Bolivia, is a globally celebrated example of citizens mobilizing against water privatization. The short-lived water privatization attempt in Cochabamba unequivocally failed, rendering this water management model untenable in the foreseeable future, both legally and in the collective conscious. The city's water company SEMAPA returned to public hands under control of the municipal government, however, attempts to overhaul the company and democratize water management have been largely unsuccessful. As a result, the city of Cochabamba continues to suffer a prolonged water crisis; nearly two decades since the Water War, access to water and sanitation remains uneven and chaotic amid cycles of severe drought. SEMAPA users in the north and center of the city face chronic water shortages primarily due to an obsolete distribution network. The most marginalized populations in the southern zone of Cochabamba are largely not directly connected to the municipal service, and rely on autonomous, self-governed small-scale water providers. Given the difficulty of acquiring water, these peri-urban communities report higher incidences of pollution and water-borne illnesses [3].

Remunicipalization literature is shifting the discussion away from the anti-privatization debates and towards building greater conceptual and empirical understanding of public alternatives [3-5]. Informed by doctoral fieldwork conducted in Bolivia, this paper seeks to build on the growing literature of remunicipalization with an analysis of the efforts to rebuild public water services in Cochabamba. During the 2000 mobilization in Cochabamba, the water movement shared a vision of democratic water provision, framed by demands for 'social control'(or control social). In the Bolivian context, social control emerged from popular struggles for greater democratic participation, and refers to a set of 
practices generated by citizens that integrate public participation (participación) in the management of public goods [6]. For the water activists, strong social control within the service provider could ensure that water is not simply a means for economic profit or state control, but a public good that is essential for life and accessible to all. Demands for social control in Cochabamba's water management thus revolved around mechanisms for democratic participation including local stewardship and community engagement in the water provider's operations.

To understand the obstacles in realizing a progressive public vision of water delivery, the concept of participation serves as a starting point of analysis. This paper builds a typology of different forms of participation, broadly categorizing participation into three main types: reformative, transformative, and nominal participation. Separating the conceptualization, intended outcomes, and practices of each form of participation helps to shed light into the processes through which political power is exerted by varying actors.

This paper then applies this framework to the case of Cochabamba's water remunicipalization. I contend that the difficulty in rebuilding a strong public water service in Cochabamba partially stems from different-and often incompatible-understandings and interpretations of these concepts of public participation. Whose interests are served, which groups are included or excluded from access to water is tied to the question of public control over natural resources.

\section{Typology of Participation: Reformative, Transformative, and Nominal Participation}

The notion of public participation is now ubiquitous among development perspectives and policy. A "warmly persuasive word" [7] (p. 58), participation has been heavily promoted and adopted in different circles over the past three decades. Difficulty in articulating a straightforward definition arises precisely because public participation is not a "single phenomenon" [8] (p. 34). A review of the international literature demonstrates its widespread use, yet does not offer a consistent typology due to the concept's malleability to a spectrum of ideologies [9]. To lend conceptual clarity, I highlight the different uses of participation, and how these differences manifest themselves in terms of intent. Specificity about the meanings and practices of participation helps to adequately identify competing perspectives of public participation in water governance.

Broadly, public participation can be defined as engaging a wider cross-section of people or organizations in decision-making and/or implementation of policy and services, alongside controlling groups, presenting a shift away from exclusive or top-down processes. To examine participation, I utilize Cohen and Uphoff's concept of asking: participation by whom, for what, and in what [8]. These questions lead to definitions that diverge dramatically into two overarching conceptualizations based on intentionality: participation as transformative, intended to create a radical shift in social, economic, and institutional norms, and participation as reformative, intended to modify decision-making processes without significantly changing the broader structures and ideologies of (market-based) power. A third form of participation exists that will be labeled as nominal; that is, a manipulation of the ideas and language of either forms above in order to gain consent and legitimacy. The following section will review the conceptualization, intended outcome, actors, and key tools and practices of these forms of participation, before applying the framework to the water sector in Cochabamba, Bolivia.

\subsection{Reformative Participation}

The early 1990s marked the beginning of the "participatory turn" [10] when participation became firmly established in mainstream development circles, commonly defined as "the process by which stakeholders influence and share control over priority setting, policy making, resource allocations, and/or program implementation" [11] (p. 237). The United Nations incorporated popular participation into a wide range of its programs, seeing it as "the organized efforts to increase control over resources and regulative institutions in given situations, on the part of groups and movements hitherto excluded from such control" [9] (p. 5). 
The label of reformative participation is apt as participation is envisioned as a way to improve development in the face of partial market failure. These are partial failures in the sense that markets are seen to have brought about massive positive change to the developing world but missed important segments and sectors of society for a variety of reasons-one of which is identified as an imbalance of voice on the part of the poor. The persisting problems of inequity and poverty were attributed to traditional development practices of donor agencies 'delivering' development solutions through large-scale, top-down government-initiated programs. Re-orienting policies towards poverty reduction via 'primary stakeholder participation' presented a way to address these asymmetries while remaining faithful to the dominant market-oriented development paradigm. Greater involvement of the poor and marginalized in the policies that affect their lives would permit local people's knowledge to be at the center of development planning, thus serving to ameliorate inequities and perceptions of injustice [12,13]. This approach emphasizes the importance of local knowledge, shifting power towards "lowers" (the stakeholders) while the "uppers" (i.e., development experts) relinquish their professional prejudices and become facilitators of local knowledge [12]. The primary stakeholders are individuals ascribed as "agents of development", and their "empowerment," the increased ability for individuals to pursue individual and collective goals, stems from increased participation in the free market economy $[14,15]$. Importantly, however, people's empowerment does not shift the prevailing structural order or undermine the market economy [13].

Greater participation is seen as a way to enhance the market because it results in a better flow of information, more accountability, and greater competition. Participation can improve the flow of information from the "demand side" which results in greater market efficiency and effectiveness [14]. Popular participation will contribute input that form more "demand-driven" policies so that agencies can "re-orient towards the customers" [15]. In other words, it makes the corporations (aid agencies) more accountable to its customers (the poor). In turn, greater participation and accountability enhances market-based strategies by acting as a check and balance to the monopolization of power that exacerbates inequalities as greater interaction with markets help indicate where improvements are needed, and accordingly diminish practices that limit competition such as collusion or price fixing. Crucially, the market is seen to produce opportunities, and participation is a way for disadvantaged groups to access these opportunities. Inclusion of 'the poor' in the market through micro-credit or micro-financing schemes provides ways to create more economic activity and generate an environment conducive to an entrepreneurial class.

Proponents of this model of participation view any increased participation as an improvement. However, accepting as a forgone conclusion that macroeconomic stability and liberalizing markets are essential precludes any discussion of these that might occur as a result of participation. The outcome of development interventions would improve by strengthening their legitimacy through local participation rather than initiatives based solely on expert-knowledge. Funding community level participatory projects through non-governmental organizations (NGOs) was viewed as beneficial or useful as governments could pass off social services to NGOs, and so-called project "transaction costs" to volunteer labor from within a community [5]. Encouraging self-management supported the disengagement with the interventionist state. Increasingly, a project's "effectiveness" and "sustainability" became linked to local participation [15].

In these invited spaces, World Bank supported policies and projects have a better chance of performing well as participants have a stake in the project, often in the form of shared ownership. This dynamic is key to understanding the reformative nature of participation. People are granted agency but within prescribed parameters. The intended outcome of reformative participation is to modify development, to correct imbalances, increase opportunities for access that will ultimately enhance the market. Poverty reduction remains the focus, yet participatory practices do not question or confront the structural causes of poverty. Reformative participation adheres to the belief that poverty can be eradicated through market-oriented economic growth. 


\subsection{Transformative Participation}

A second broad category of participation can be conceptualized as transformative, given that its principle objective is to utilize participation as a way to dramatically transform the cultural, political, and/or economic structures that reproduce poverty and marginalization. Early proponents of participation, such as Brazilian educator Paulo Freire, sought to challenge patterns of dominance through empowerment [16]. Waddington and Mohan equate empowerment to developing a personal political literacy, building consciousness and confidence to exercise agency [17]. This personal development can initiate larger processes of bottom-up group mobilization around collective experiences of marginalized groups that seek to challenge hegemonic order and market structures. Transformative participation often occurs in autonomous "invented spaces" of participation [18] to organize and undertake collective grassroots actions and tactics intended to resist existing structures [19]. Transformative participation can also take place in invited spaces where larger structural shift in state-policy making can occur. Here, the act of participation is transformative if it implies a transfer of power.

While some critics have grown disillusioned with participation due to the conflated understandings of the concept and ensuing problematic results [20], others see a resurgence of the potential transformative possibility of participation through critical reflection [21-26]. Participation can contribute to a lasting social change when it is not used as a quick fix or technical solution [18]. Locating participation in "radical politics of social transformation" reaffirms the concept's counter-hegemonic roots [23] (p. 79). Mohan and Hickey propose to reposition participation within "radical politics of development" by reframing participation that merges facets of liberal citizenship, as in formal rights and political channels, with a civic republican approach based on citizens' collective engagement in decision-making [24] (p. 251). They outline the following conditions for transformative participation: (1) form part of a broader political and radical project; (2) move beyond the confines of particular interventions and participate in 'underlying process of development' towards social change (e.g., inviting citizens to engage with core state activities); and (3) secure citizenship participation in order to "progressively alter the processes of inclusion that operate within particular communities, and which govern the opportunities for individuals and groups to claim their rights to participation and resources".

The goal of transformative participation is to radically transform a situation to create meaningful social and economic change through empowerment by participation of those excluded from economic or political processes. White argues that "participation as empowerment is that the practical experience of being involved in considering options, making decisions, and taking collective action to fight injustice is itself transformative" [16] (p. 68). The process of transformative participation seeks to exert control over decision-making, sharing knowledge and skills, and the redistribution of power, resources, and benefits [25]. While the goal is a structural transformation, the experience of reversing an injustice (or attempting to) is also viewed as meaningful and transformative in and of itself [16].

As it is typically understood as a movement "from below" to transform existing structures, the main actors of transformative participation are those making demands, the voice of the oppressed or dispossessed; citizens that are excluded from political and economic processes, who are often organized in community organizations, and social movements. This includes people who organize, mobilize, and make demands, and negotiate for greater participation at the decision-making level. Governments are also involved in civil society engagement through social reforms, the redistribution of wealth, and by opening spaces for political participation. NGOs sometimes act as advocates for transformative participation and can be important allies in creating spaces for negotiating demands [16] (p. 2). Practices and examples of transformative participation include, amongst others, participatory action research, mobilization and social movements, and participatory governance.

\subsection{Nominal Participation}

Worth noting is a third category of participation employed by various entities that cuts across ideologies. Nominal participation is a problematic type of participation insofar as it is typically used 
to legitimize a project or policy rather than seeking genuine input or alternative ideas. Whereas advocates of reformative participation believe that certain participatory practices will lead to market improvements, nominal participation can be considered a "performance of participation" [26], as the intent is to reinforce the standing social order. The disingenuous intent of nominal participation is veiled by the haziness surrounding the concept and the prevalent notion that any form of participation should be cultivated. Essentially, nominal participation is a repurposing of the concept of participation, or as Brown (2004) states, "the co-optation of faddish language in the service of the status quo [27] (p. 249).

As with reformative participation, spaces of participation are "invited spaces" [28] that occur at official venues where agendas are carefully circumscribed by external agents in a way that curtails public engagement. Here, meaningful participation is not fostered as questions and discussions are discouraged resulting in a one-way flow of superficial information to citizens from officials or authorities; participation is promoted only in appearance. This kind of empty participation legitimates decisions taken by 'power holders' because it appears as though all stakeholders' voices were considered [29], yet these meetings merely amount to "displays of participation" [16].

The intended outcome of nominal participation can be to reinforce the status quo of power dynamics, gain legitimacy, and appease parts of the population. Participation is used to depoliticize activities and enlist community members' support for specific projects and practices [30]. The bureaucratic mechanisms of nominal participation serve to reproduce social order, state authority, and industry practices, while social inequalities remain obscured. On the other hand, poorly operationalized participation or lack of capacity to foster participation of the reformative or transformative kind can also lead to nominal participation.

Different state actors across the ideological spectrum exploit participatory practices towards their own ends: often to gain access to funding, participatory practices must be included. Main actors are political parties and state representatives at all levels, NGOs that fail to incorporate participatory practices properly, and public or private companies whose official participatory mechanisms are largely hollow. Practices include community development, consultation and informing.

The realities on the ground are such that participatory practices do not fit neatly into these categories, thus the typology of reformative, transformative, and nominal participation laid out above serves as a heuristic reference point for deciphering different types of participation. The framework nevertheless helps shed light on different understandings of participation and the tensions created by them. There appears to be a broad consensus that participation is important, particularly within public institutions, yet the lack of clarity surrounding the meaning of participation, and the inherent tensions between different perspectives, contributes to the confusion of what participation should be.

\section{3. 'Social Control' and Participation in Cochabamba's Water Sector}

Applying the participation framework to the water sector in Cochabamba, Bolivia, reveals that the outcomes of participation can differ from intents, and that conflicting forms of participation have created tensions among water users, policy makers, and activists in the city. The period of privatization of Cochabamba's water services is a prominent example of reformative participation. More transformative forms of participation can be observed in the water movement that culminated in the Water War of 2000 that rejected privatization and demanded water services be returned to the public sphere. The historically important concept of social control adopted by the water movement this time centered around the demand and the resolve to democratize the water system through greater citizen involvement in governance [31] (See Cielo (2009) for historical context and experiences of social control in Bolivia [32]). The Water War can be understood as a catalyst for broader change in Bolivia, sparking further resource wars (Gas Wars of 2003 and 2005) and a shift to the left with the election of current president, Evo Morales, and the Movement Towards Socialism (MAS) party in December 2005, assuming office in January 2006 [33]. Morales responded to the water sector demands with the formal recognition of the Right to Water and the recognition of the traditional model of usos 
$y$ costumbres or 'uses and customs'. New state institutions dedicated to water management at the national level incorporated mechanisms of participation and social control. I argue that although these formal mechanisms were based on the demands for transformative participation that grew out of popular unrest, they have resulted in nominal participatory practices that have served to work against meaningful change. The attention paid to social control in the formal water sector has been rhetorical, with contradictions between official discourse and practice.

The participatory efforts implemented in Cochabamba's municipal water company, SEMAPA, did not transfer decision-making control to the population, thereby maintaining the power imbalance between marginalized users and management in municipal services. The institutionalization of participation and social control has not resulted in a progressive municipal service.

\subsection{Water Privatization and Reformative Participation}

The privatization of Cochabamba's water utility formed part of the wave of neoliberal restructuring in Bolivia that applied market logic to purportedly improve inefficiencies in public services. By the 1990s, privatization was a precondition to borrowing from major financial donors [34]. In 1996, the World Bank threatened to deny $\$ 600$ million in debt relief in the Bolivian government did not privatize the water sector [35]. At the time, popular participation mechanisms had been introduced through the Law of Popular Participation, in part to provide the supposed social stability needed to attract private investors [36]. As such, the participation sought under water privatization can be understood as reformative, with the intent to use participation as a tool to expand market access. In line with neoliberal pro-poor policies, people participate as customers in a 'transition' from poverty.

In a city of close to half a million residents, Cochabamba's water company, SEMAPA, was critically over-capacity and viewed as a textbook example of the public sector's inability to properly administer basic services. The first bidding process was unsuccessful and the second, two years later under President Hugo Banzer's administration, produced a sole bidder. The concession contract was signed under the Bechtel consortium, Aguas del Tunari, on 3 September 1999. Aguas del Tunari did not take over operation until November 1999, when the Potable Water and Sanitation Law 2029 passed. The law eliminated basic service subsidies and enforced the commercialization of water and the privatization of municipal water systems [36,37]. Aguas del Tunari had the right to seize water sources in their concession zone, which included the water sources used by the various small-scale systems in Cochabamba's peripheral Southern Zone, and the irrigating farmers' sources in surrounding rural areas. The communities reliant upon small-scale water systems, as well as irrigating farmers were the first to mobilize against privatization, to rescind the contract and reverse the law that granted monopoly rights on water sources traditionally used in a collective way [38].

The scale of the irrigation networks in the Cochabamba Valley and the complexity involved in expanding the city's water system to encompass the self-managed water systems of the periphery only became clear to Aguas del Tunari after the contract was signed (Anonymous Interlocutor, Interview, 2014). The costs of the projected expansion were offloaded onto the urban residents connected to the service, and as a result user fees skyrocketed to unaffordable levels. Different sectors thus united against privatization, forming a movement to reaffirm social control of water systems, demonstrating how neoliberal reformative participation failed to provide the stability expected through the Law of Popular Participation.

\subsection{The Water War and 'Social Control' as Counter-Narrative}

The privatization of Cochabamba's water services provoked a broad mobilization of Cochabamba residents that took to the streets for several months of protest, culminating in eight days of intense confrontation in early April 2000 (For extensive accounts of the Water War events see Olivera and Lewis 2004 [39], Crespo et al. 2001 [40], Shultz 2008 [41]; see Bustamante et al. 2005 [38], and Laurie 2011 [42] for gendered analysis). These events, known as Cochabamba's Water War, are commonly upheld as a model of successful anti-privatization mobilization, as the private contract for the city's 
water was rescinded. The demands for social control made during the Water War were conceived as a way to widen the scope of democratic control over public services and the use of resources. Motivated by the lack of transparency during the privatization process, social control of water management became part of the counter-narrative to the reformative participation of the neoliberal order.

The main demand emerging from the Water War mobilization was the democratization of decision-making in water management. The implementation of social control provided an alternative to privatization, as well as a remedy to the problems of previous state models of water management. Through participation and collective action via La Coordinadora (The Coalition for Water and Life), a coalition of rural and urban residents, the citizens of Cochabamba managed to oust a major multinational from their city; participation would be a demand to move towards positive changes in the newly reinstated SEMAPA. According to Oscar Olivera, one of the key organizers of the anti-privatization protests, the Water War was about achieving universal access and adequate sanitation services and to ensure that unaffordable tariff increases would not re-occur. Control of water management was a political demand that would be achieved by gaining control over the decisions that affect people's livelihoods, making public participation a fundamental issue (Anonymous Informant, Interview, 2014).

During the Water War, the concept of usos y costumbres was championed as an alternative to the privatization model. According to usos y costumbres, water governance is decided among the people through mutually-agreed upon arrangements, based on peoples' needs rather than profit motives. This emphasis on people-centered governance offers an example of a transformative participation model. Garande and Dagg reference Micherner's argument that people-centered participation empowers people or community when there is collective consciousness-raising, "enhanced(d) local management capacity," and greater "confidence in Indigenous potential" [43] (p. 420), [44]. Usos y costumbres, grounded in Andean principles of reciprocity and redistribution [45], can be based on Indigenous traditions even when community members might not explicitly identify as Indigenous (Lazar and other scholars on Andean identity explain the transience of Indigenous identity, often used in strategic ways [46]). Here the empowerment lies in the fact that community members are involved in the decision-making process through participatory assemblies and the democratic selection of leaders. Although not without flaws, the emphasis on transformative participation found among self-governed systems in the Southern Zone provided a model of water governance that Cochabambinos could uphold.

Returning to the idea that communities felt ownership over their existing water systems, they were outraged that a private company could expropriate the systems and the water sources that belonged to them. This points to Cleaver's [47] (p. 51) distinction between autonomy as an "expression of agency" or a "necessity imposed by constraint." Initially, the self-governed systems were formed due to the lack of municipal services (constraint), but following the threat of privatization, the emphasis on protecting autonomy and upholding traditional water rights that emerged can be understood as a demonstration of agency. This is evidenced by the formation of ASICA-Sur, now known as ASICA-SUDD-EPSAS (Association of Community Water Systems of the South), an umbrella network of water committees in the periphery, or Southern Zone, of the city. The protection of these systems (especially against the threat of privatization) became an important point of mobilization, as they provided an alternative to market-driven forms of water governance.

These three ideas-that water cannot be commercialized, public participation and social control is critical, and defense of usos y costumbres - formed the basis for the water movement's vision for the restructuring of SEMAPA:

Of course there are many problems to be faced; however, the challenge accepted in April by the population as a whole, and by La Coordinadora especially, is to consolidate a company of potable water and sewage that maintains its public character, under control of the population and moreover, that is efficient, that has the capacity to improve and expand its services, and whose operation is transparent. To achieve this goal it is necessary to consolidate a management model in SEMAPA that facilitates the active participation of the 
organized population in the design of general policies and decision-making, and what's more, that permits the audit of company activities by grassroots organizations (La Coordinadora proposal, 2000).

La Coordinadora made these explicit calls for social control with the expectation that these measures could solve, or at the least help address, the various problems within SEMAPA that predated-and made the company a target for-privatization, however, this vision faced pushback from the outset.

\subsection{Nominal Participation Normalized}

Nineteen years after the Water War, SEMAPA bears the tagline "clear and transparent." Public participation and social control are operationalized via bi-annual Audiencia publica de rendición de cuentas, a public accountability hearing. These meetings are structured as an hour-long presentation followed by a fifteen-minute question and answer period, organized by SEMAPA's Transparency Unit. During one meeting, the room was half full: the majority in attendance were SEMAPA workers complying with their work obligations, and 14 members of the public, who were mostly community representatives. Available records from previous and subsequent meetings denote the same poor attendance rate. In later discussions with community leaders-dirigentes, heads of water committees and cooperatives in the Southern Zone-many were unaware of the meeting dates and had not received the letter of invitation. Instead, they lamented the lack of communication from SEMAPA.

Aside from the poor promotion of the meeting, the scheduling is problematic. Held mid-morning on a Wednesday, the busiest market day of the week after Saturday, the meeting time conflicts with most work schedules. Further, SEMAPA's headquarters are located in uptown Cochabamba, which typically requires a one-hour commute from the Southern districts, depending on traffic. Location and timing present accessibility challenges. Additionally, public records of meeting minutes are not shared widely. The meeting itself consisted of an information session of mission statements, overviews of the year's projects, and general financial information presented by various SEMAPA managers, who occasionally stopped to answer their cell phones. For the question and answer session, the attendees were not given the floor; rather, questions were submitted on paper to be read out by a SEMAPA representative. The different managers answered the questions, often deflecting problems, and quickly moved on to the next question without leaving time for deliberation or discussion. There were a total of eight questions that were answered within twelve minutes. This is the heft of the current mechanism for social control and public participation.

These meetings do not amount to the robust public engagement called for during the Water War of 2000. Far from observing meaningful exchange, the mechanisms in place today reflect nominal participation, promoted in rhetoric only. Here, decision-making is contained to exclusive circles, and participation is a display of public meetings whereby the water utility can claim they are fulfilling their obligation to public participation and social control. The following two sections will explore the power dynamics that prevented transformative participation from taking hold in SEMAPA, and SEMAPA's institutional inertia as continued corruption and political influence plagued the company.

The final section demonstrates how nominal participation has become normalized in formal spaces of the Bolivian water sector at the municipal, departmental, and national levels. As the 'party of social movements,' MAS buttressed a discourse of participation and social control, signaling a shift towards transformative participation. However, the party's actions have led to the fragmentation of social movements, the reproduction of clientelist relations and restricted access to higher-level decision-making spaces.

\subsubsection{Defining the "New" SEMAPA: Early Divides}

Directly following the Water War, SEMAPA reverted to an autonomous decentralized public utility. The conservative national government of Hugo Banzer was in power, but the task to rebuild SEMAPA occurred at the local level, with the New Republic Force (NFR) party in the mayor's office [48]. 
SEMAPA was headed by a Board of Directors that consisted of municipal officials. The population of Cochabamba was dissatisfied with this return to the former state model that had been riddled with problems. Moreover, they were distrustful of this Board because of their involvement in the utility's privatization-they had not only endorsed the concession contract but also supported Aguas del Tunari in claiming economic losses for the breach of contract and forceful exit from Bolivia [49] (p. 34).

Eager to establish an alternative model of water management, La Coordinadora remained active following the Water War, holding consultations and workshops to put together a proposal for SEMAPA's restructuring. La Coordinadora understood social control as a way to improve the public entity so it would not be a target for privatization [50]. The push towards democratizing public services was important for all sectors of the population, even those not connected to the municipal network, because it is linked to struggles over natural resources [51]. La Coordinadora's initial proposal called to dissolve state property and replace the utility structures as common property (La Coordinadora proposal document). However, the idea of SEMAPA as common property was viewed as too radical and La Coordinadora members preemptively modified the proposal to be more palatable. The second proposal was penned by the College of Professionals of Cochabamba, a group composed of professionals across 17 fields that had been involved in some way in the Water War. This group had strong ties to the mayor's office and their proposal included input from SEMAPA workers [49]. Finally, a third proposal was presented by a junta vecinal, a neighborhood council that was also aligned with the municipality.

The differentiating factor between the three proposals is the amount and type of participation. La Coordinadora's proposal exemplifies a model of water management, often referred to locally as 'public-social,' that would place decisions about the water utility directly in the citizen representatives' control. With six social representatives, the 'public' would hold majority vote holders in the Board of Directors that would be held accountable through public assemblies. The other two proposals conceived public participation quite differently, placing SEMAPA firmly under government control, with social representatives being a minority on the Board of Directors. This composition allowed for spaces of civil society input, but not the final decision. According to my earlier categorization of participation, these state-led spaces do not automatically preclude transformative participation, but in Cochabamba it is often tied to a paternalistic view of social control that persists today, as exemplified by this quote from a former manager at SEMAPA:

(Participation) is a way to administer the state that I do not agree with much ( . . ) I consider this country one that has not reached maturity of First World countries of hundreds or thousands of years of democracy. Are you going to consult an immature [country], what decision will it take? One example, I have three children, who are now grown, but when they were younger [I'd ask] what would they like to eat today? One will say chicken, the other hamburgers, and the other will say 'I want ice cream.' But ice cream is not nourishment. Second, I cannot cook three different things, and third, my budget does not allow it, I only have enough for eggs and rice. So why ask? (Former General Manager of SEMAPA, Interview, 2014).

In other words, technical experts are seen in this model to be better suited to address water issues than the average citizen. Here, the 'technical problem' of water scarcity requires 'technical solutions,' where public input is not valued.

A new statute for SEMAPA was approved on 25 October 2001. In the end, the outcome of the citizens' directory was a much less radical version than envisioned by La Coordinadora. The composition of the board was three citizen representatives from different districts of Cochabamba, two representatives from the municipal government, one from the College of Professionals, and one union representative. With a minority of citizen representatives serving on the Board of Directors, the participatory criteria of 'inclusion' was fulfilled, but not that of 'control.'

Several factors contribute to the inability of the water movement to achieve its initial demands for transformative participation. By the time discussions around restructuring SEMAPA with social control 
were solidifying, a year after the Water War, La Coordinadora had lost mobilization power [49]. It had waned because actors were preoccupied with different regional and national movements. Several of the informal leaders of $\mathrm{La}$ Coordinadora were beginning to shift their commitment away from water issues, in order position themselves politically to align with MAS (Anonymous Interlocutor, Interview, 2014). With decreased numbers, maintaining pressure on the municipality to achieve demands proved difficult [52]. La Coordinadora fostered unity during the Water War by identifying a common enemy, the privatization of water services, which allowed people to band together regardless of socio-economic standing. The distinct motivations people had for joining the Water War protests-protecting water sources, guarding autonomous water systems, and fighting against rising tariffs—did not translate to a consensus going forward in the restructuring of SEMAPA. La Coordinadora's initial ideas were viewed as too radical and were thus tempered in order to achieve a modicum of social control in the utility's management [53].

The challenges in rebuilding SEMAPA following the Water War reflect the elite resistance to restructuring and transformative participation, particularly by actors within the municipal government who wanted to preserve SEMAPA as a source of political capital [52]. SEMAPA's workers' union formed an unlikely alliance with the local elite. The union's leadership aligned itself with SEMAPA's administration's stance on maintaining the previous management model $[47,49]$. The workers lobbied to preserve their role of relative power within SEMAPA and were in favor of limiting the number of citizen representatives on SEMAPA's Board of Directors, and consequently, the extent to which the company's restructuring could lead to significant and meaningful participation [48].

Wainwright points out the importance of examining the organization of labor and human relations to see how the relationships can contribute to democratizing public institutions. She argues that relations between labor and management are "decisive to the flows of information, knowledge, and problem solving among staff and between staff and users," and that the "combination is vital to achieving the goals, the measurements and the dynamics of a different kind of economic logic" [50] (p. 88). Despite the terse history of cooperation between management, workers, and users, there have been instances of worker-led, management supported collaboration. However, in the crucial moments following the Water War, La Coordinadora could not rely on the full support of SEMAPA workers, a considerable blow to the water movement.

While La Coordinadora's initial ideas did not materialize they did manage to ensure some mechanisms of social control within SEMAPA. They pushed to include a "vigilance and social control unit" within the company, with the function of investigating instances of corruption, and to track inefficiencies. The unit was meant to be independent and consist of SEMAPA workers and civil society [48] (p. 125). This unit took years to approve, and was eventually established as the "Transparency Unit," mandated by the Ministry of Transparency, to deal with the complaints that correspond to SEMAPA. La Coordinadora was also able to secure the statute for citizen representatives to be approved by the Board of Directors [49].

\subsubsection{Institutional Inertia}

The limited mechanisms for social control of citizen representatives faced problems from the first elections of a new SEMAPA Board of Directors. These were held in April 2002, the same year as the national general elections. People were not as motivated about water issues as they had been two years previous, however, and more importantly, most were preoccupied with the larger elections. With minimal publicity, the mayor sent last minute notice of the SEMAPA representatives' elections, to be held before the Departmental electoral court [36]. Moreover, voters were identified through a database of ELFEC users (the electric utility Empresa de Luz y Fuerza), limiting the vote to one per family (the person whose name appears on the bill), thereby circumventing the participation of tenants who do not pay the bill directly [36]. Even with this low voter turnout (3.6\% of eligible voters) the elections were contested due to the disorganized voting stations, and accounts abound of people being told 
where to mark the ballot by SEMAPA workers and those administering the vote. Recall elections were held, but subsequent elections have remained problematic [36] (p. 48).

Once holding positions, the citizen representatives received little to no training on how to communicate with the public, or methods to evaluate SEMAPA's plans and operations. Graver still was the ability of other members of the Board of Directors to politically influence the citizen representatives. Due to their marginalized position of minority vote, citizen representatives often limited themselves to petitioning for improvements in their sector of the city alone. Other times, they would vote in favor of the Board in exchange for positions at SEMAPA for friends and family [36]. At worst, citizen representatives were directly offered financial compensation in exchange for their vote, or silence regarding corruption (Former citizen representative, Interview, 2014).

By 2010, the positions of citizen representatives of the Board of Directors quietly dissolved. SEMAPA was no longer holding elections for these posts and no one protested (Anonymous Interlocutor, Interview, 2014). People lost faith in the ability of citizen representatives to change the internal dynamics of SEMAPA. In short, it was a failed experiment because it did not provide a strong voice for the public, as decision-making power was not transferred to the citizens of Cochabamba. The momentum of the water movement had weakened, and with diminished social pressure, SEMAPA returned to the status quo prior to privatization, a vehicle for corruption and political gain, ultimately having adverse effects on network improvements and expansions. Institutional instability was linked to the high turnover rate of General Managers in SEMAPA. Appointed by the mayor, General Managers typically serve one to two years heading the company, though some periods have seen up to five changes in General Manager in one year (Former citizen representative, Interview, 2014).

The 'overstaffing' of SEMAPA is a point of contention among most people interviewed that work in the water sector (outside of the company) and citizens of Cochabamba. Accounts of corruption included inflating the quantity of materials necessary for a particular project and writing off equipment and supplies that never arrived. These repeated scandals diminished SEMAPA's chances for securing funding from international financial institutions that were already reluctant to invest in public companies [48]. Once funds were invested, the instability of the company led to repeated cancellation of financing from the Inter-American Development Bank (Anonymous Interlocutor, Interview, 2014).

In the construction of municipal water projects, the lack of strong participatory mechanisms in SEMAPA have been detrimental to increasing water provision in the city. One of the few successfully completed major infrastructure projects was the "Improvement of Potable Water System of Southeast Zone of Cochabamba City," commonly known as the JICA project, as it was funded by the Japanese International Cooperation Agency which has worked in Bolivia for over three decades. The application for the project was first sent to JICA in 2004, and the project was completed in 2010. The goal was to provide water to 22 communities in the Southern Zone of Cochabamba, which would benefit an estimated 50,000 inhabitants, with the expansion of a water treatment facility, the construction of adduction and impulsion lines, the construction of a principle distribution network, and materials for secondary networks that would connect communities to the main network. SEMAPA carried out the project with financial support from JICA. Construction began without public engagement on the project and faced its first obstacle when the community surrounding the initially identified treatment facility blocked its expansion because they did not construction disruptions in neighborhood. SEMAPA thus shifted course to expand a different existing treatment facility, Aranjuez, situated this time in the North of the city. Once more, without employing participatory mechanisms, the project faced yet another obstacle. The water source for the Aranjuez facility is located in a nearby community that lies outside of SEMAPA's jurisdiction; its inhabitants with usufruct rights did not permit the increased water use sought by SEMAPA.

This lack of public participation resulted in the current state of the project: newly built infrastructure, but without water. When Evo Morales arrived to inaugurate the project (in October 2011), he opened the tap and water did flow freely, but without a consistent water source the network is working at $10 \%$ capacity, accelerating pipe decay (SEMAPA worker, Interview, 2014). Rather 
than serving the neediest population of Cochabamba in the Southern Zone, the treatment facility improvements have however benefited the residents of the Aranjuez district, one of the wealthiest neighborhoods in the city in the North Zone.

Certain measures of public participation in SEMAPA were introduced via the central government. As of 2011, SEMAPA has been required to comply with the nation-wide community development initiative known as DESCOM (Desarrollo Comunitario y Fortalecimiento Institutional-Community Development and Institutional Capacity Building), part of a requirement of most externally funded projects that need to meet the standards for the international Technical Economic Social and Environmental Assessment. In SEMAPA, DESCOM consists of hosting workshops with communities, water committees and cooperatives, on various water provision related topics, for example tariffs or network maintenance. Externally hired consultants typically run the workshops (SEMAPA worker, Interview, 2014). However, as one SEMAPA employee explained, in practice, little attention is paid to the social aspect of the assessment and projects. Often excluding community members from water projects, citizens do not learn how to use the service or receive training on network maintenance. Contracts for water provision between a community and SEMAPA often go unsigned, or SEMAPA would not receive payment for services, ultimately resulting in unused water systems. The national guides are based on previous DESCOM guides elaborated by the Inter-American Development Bank, which clearly state that the beneficiaries of the projects are co-responsible for the project planning, execution, and evaluation. It is, however, difficult to determine the success of DESCOM beyond these guidelines and whether it fosters participation deeper than a consultation process. SEMAPA workers noted that DESCOM is even more complicated in a dense urban setting:

We didn't have a person to do this work (of DESCOM). So the engineers finally started the work and said "(the pipe) will pass here" and the people were opposed, there were blockades and strikes, they set fire to machinery, they sequestered the engineers for a full day. ( ... ) Everything was paralyzed, and the work did not start again until they explained it was the only option, the only way. In the end, the only way was to enter by force, with the police, with the mayor, with public force (SEMAPA worker, Interview, 2014).

This conflict in the Southern Zone, which occurred in late 2013, is not uncommon when SEMAPA enters a neighborhood, with no prior warning or explanation, to install piping that would serve a different neighborhood. At other times, burst pipes or damaged sewage systems are left unattended for months. Across my interviews with members of water committees and cooperatives in the Southern Zone it was clear that collaboration and communication between the Cochabamba population and SEMAPA is badly wanting.

\subsubsection{MAS and the Rhetoric of 'Social Control'}

Optimism and expectations for improvements in the water and sanitation sector rose dramatically after the election of Evo Morales and the MAS government in 2005. The new government championed social control and participation in official discourse and policy while formalizing it in the water sector. The language utilized throughout legal and policy documents upholds public participation in governance and can be interpreted on the surface as transformative, but as this section illustrates, public participation is contained in state sanctioned spaces with little facilitation of participation in higher-level decision-making. Only organizations and social movements that are not perceived as a threat to MAS are invited to take part, resulting in a more nominal form of participation.

Morales ran on a platform of Indigenous rights, dignity, and sovereignty-a clear break from the colonial and racist regimes of the past [54]. He also presented a shift from neoliberalism, predicated on the promise of nationalizing key industries and redistributing wealth through social programs for the most marginalized. A key principle of the MAS government is the Indigenous concept of vivir bien, or 'good living', defined as "encounter and progress through diversity and 'inter-culturality,' harmony with nature, social and fraternal life, national sovereignty in all field[s] and internal accumulation 
with quality of life" [55]. The concept is tied to Indigenous dignity and frames MAS' Water for All plan wherein water, and access to water, is fundamental to life, based on integrated water resources management that is sustainable and participatory [55].

MAS positioned themselves, and projected themselves internationally, as defenders of Pachamama, Mother Earth. Morales' successful lobbying efforts led to the ratification of United Nations Resolution (64/292) in July 2010 that expands the United Nations Declaration of Human Rights to recognize the Right to Water. The fundamental Right to Water was also an important part of the new Bolivian Constitution, putting the onus of guaranteeing access to water on the state, and shifting "ownership" of water sources to public (read state) property, granting the state "exclusive authority" over water resources [56] (Article 298, II). At the same time, the formal recognition of traditional and customary uses of water under Bolivia law and the creation of official licenses or registries for small-scale water providers became a large focus of water sector reform. The new potable water law (no. 2066) now created licenses for large providers such as municipalities (e.g., SEMAPA) and water committees, whether Indigenous communities, peasant unions, or neighborhood associations, which would need to be registered as an EPSA (Entidad prestador de sanamiento y agua-water and sanitation provider). The changes in legislation were significant as they signaled a shift in the dominant neoliberal model of water commercialization, and provided protection against the threat of privatization [57].

Another of Morales' first presidential acts was the creation of a national water authority. The Water Ministry encompassed vice-ministries responsible for policy, planning and projects in the areas potable water and basic sanitation, irrigation and water resources, environment and climate change (the current iteration is the Ministry of Mother Nature and Water, under which fall the Vice Ministry of Potable Water and Basic Sanitation, the Vice Ministry of Water resources and Irrigation, and the Vice Ministry of Environment, Biodiversity, Climate Change and Forest Management and Development). Notably, prominent figures in the anti-privatization water struggles were appointed as minister and vice-ministers, including Luis Sánchez Gómez, appointed as Vice-Minister of Basic Services in 2006, and Rene Orellana, appointed as Minister of Water in 2008. These types of appointments are how MAS projects its stance as a 'party of social movements'.

Under the umbrella of the Water Ministry, MAS established several corresponding agencies, including the Fiscal and Social Control Authority (AAPS). AAPS is the entity responsible for creating a registry of the EPSAs in order to regulate water services. The process involves providing a registry or license that provides legal recognition to the EPSAs, offering jurisdictional security to the water service provider by registering the water source. The purported goal is to provide the EPSA protection against expropriation and operational support to strengthen the systems. Ideally, registering water sources and their uses helps avoid conflicts between communities, and importantly, creates a database of the existing water systems (AAPS Director, Interview, 2014). For the smaller, community-run EPSAs, registration came with the expectation of some form of benefits from the government. Importantly, for many communities the EPSA title delivered a guarantee of their system's autonomy, and thereby maintaining social control over their own water governance.

The fate of Cochabamba's small-scale community-run systems, or EPSAs, present a point of contention in the discussion of the potential expansion of SEMAPA's infrastructure [58]. Particularly, the registration of EPSAs calls attention to questions of jurisdiction and zones of responsibility. The new legislation eliminated these zones, and through registries and licenses has granted small-scale systems jurisdiction over their water services, making them equal to SEMAPA before the law. This complicates planning and the expansion of SEMAPA into zones already serviced by smaller systems. Cases of parallel projects, competition and conflict between municipalities and communities over infrastructure and treatment facilities are common in the Department of Cochabamba.

Water committees and cooperatives in Cochabamba have engaged in a series of "multi-scalar strategies" to preserve their own systems [59], including registering as EPSAs, as noted above. Conversely, other water committees and cooperatives maintained that the registration process is a threat to their autonomy. This reluctance to register as EPSAs possibly stems from the distrust that state 
institutions are acting in communities' interest. A viewpoint held by many within institutions is that the sources do not actually belong to the communities, that the state is the regulator of water resources and their exploitation. As a water activist explained, the new legislation for diminishing the power of communities is a process that favors the state: "those who seek access to water are increasingly forced to the state, the laws, the courts" (Anonymous Interlocutor, Interview, 2014). Where disputes were previously settled between communities through uses and customs, several state agencies are now set to intervene. Further, Seemann faults the legislation for idealizing community harmony [56]. Echoing Perreault's [60] argument, Seemann acknowledges that inclusive water governance can be beneficial for communal water rights yet rather than leveling the playing field, participating in the liberal justice system excludes communities unable to record their water consumption through uses and customs: "formal recognition of local hydrosocial territories necessarily implies the non-recognition and illegalization of a variety of non-formalized hydrosocial territories" [61] (p. 169). Seemann concludes that MAS" approach forms a "disciplinary water governance" as the formalization of the water sector can obscure inequalities in access to resources [54].

The potential for registries and licenses to heighten inequality must be evaluated against the material impact of EPSAs recognition. As of 2014, according to information provided by AAPS, 46 EPSAs had registered in Cochabamba. Many water committees expressed frustrations over the minimal assistance received—obtaining formal recognition had not changed much. Without regulation over drilling wells, or analysis of water samples, AAPS functions as an outlet for complaints or conflicts that are not resolved within communities, to the point above that the formalization of the water sector has created a certain dependence on the state. A change in interactions with the state is observed in the way social movements and communities increasingly place demands upon MAS rather than seek their own solutions or alternatives, as had been done previously. Returning to participation, the EPSA registration process demonstrates the limited space for citizen participation. In an institution that purports to practice social control, AAPS fails to implement mechanisms for transformative participation thereby excluding many communities' interests. Whether simply lack of capacity or commitment to foster spaces of participation, the public's demands are often overlooked. This has important consequences for sector funding, and detrimental impacts for services for groups not aligned with the government.

The policies and projects under the government's "Water for All" campaign seek to prioritize districts that lack access to water with a heavy focus on rural areas and irrigation programs. The Vice Minister of Water (at the time) proclaimed universal access for $99 \%$ of Bolivians would be achieved by 2020 (Vice Minister of Water, Interview, 2014). However, the national figures are more modest, according to the 2012 census, $80.8 \%$ have water access nationally, and in Cochabamba the figures are $68.7 \%$ for water and $54 \%$ for basic sanitation [62]. Of the basic sanitation number, $54.6 \%$ consists of piped sewage systems, while $45.4 \%$ consist of alternatives such as septic tanks and cesspits [62]. Further, the national statistics can be misleading because they focus on infrastructure, ignoring other criteria of quality, quantity and continuity of services [63]. The national government projects focused on water and sanitation have had mixed outcomes. In reference to one of the largest projects under the Water for All campaign is Mi Agua, several reports outline subpar construction of these projects, hastily executed to demonstrate results in order to garner favor with voters or reward support (NGO worker, Interview, 2014).

This kind of exchange is not unique to the MAS government. Lazar depicts the historical norms of patronage politics in Bolivia; what is distinct in the MAS regime is the position the party takes as the voice social movements [46]. The critique leveled from the left charges Morales of co-opting social movements. As Regalsky [64] (p. 47) explains, the push for political reform and Indigenous recognition in fact "subordinated [groups] to the state," reinforced the party system, thereby demobilizing the movements due to loss of leadership and neutralizing the critical lens (Anonymous Interlocutor, Interview, 2014). Hierarchical clientelist relations between the political party and voters are reproduced, 
yet more obscured under the MAS government. This limits social movements' abilities to work beyond the frameworks proposed by MAS.

In the water sector, this dynamic has led groups to align themselves with MAS' position specifically to gain funding. The most notable example in the Cochabamba context is ASICA-SUDD-EPSAS wavering position regarding the autonomy of water committees. ASICA-SUDD-EPSAS is the umbrella organization representing many small-scale water systems of the Southern Zone. At its inception, in 2004, the organization's stance was a defense of these water systems against dispossession by foreign capital. ASICA-SUDD-EPSAS was open to working jointly with SEMAPA on the administration of water and sanitation services, yet was steadfast about maintaining their autonomy [65]. Influenced by the political climate, today the organization's position has shifted to align with the conception of EPSAs existing within an overarching municipal system, viewing the small-scale systems as unsustainable. They no longer fully uphold the community management alternative (NGO worker, Interview, 2014). Being less critical of MAS was a tactic to gain technical or financial assistance to help maintain the systems, at the cost of the association's ability to organize independently from the state. Paradoxically, any benefits received from aligning with MAS have not necessarily translated to advantages for the water committees of the Southern Zone. Instead, the organization is fragmented and no longer presents a strong unified front. ASICA-SUDD-EPSAS has weakened substantially, especially since the loss of funding from international donors.

Once numerous in the Cochabamba Valley, the presence of internationally-funded NGOs appears to be on the wane. Since the controversy surrounding TIPNIS (Territorio Indigena y Parque Nacional Isiboro Sécure), there is an increasingly contentious relationship between MAS and NGOs critical of the government's extractivist policies that contradict their position as champions for the environment, Indigenous populations [66]. The Trans-Oceanic Highway, a joint infrastructure mega-project between Bolivia, Brazil, and Peru, consists of a large-scale highway across the Isiboro Sécure National Park TIPNIS affecting over sixty Indigenous communities. NGOs highly critical of the road for its environmental impact on the Amazonian rainforest and the displacement of Indigenous communities were reproached and threatened by MAS, and in one case expelled from the country (see McNeish [33] and Achtenburg [62] for further reading).

In May 2015, Morales issued Decree 2366, opening natural protected areas to mining and oil extraction. A month later, the President threatened to expel "imperialist" NGOs that challenge the decree [67]. On the other hand, as Spronk points out, the basic funding structure for the water and sanitation sector in Bolivia is unchanged since the neoliberal era, reliant on external funding from international cooperation [68]. The Minister of Finance reported 8.427 million bolivianos assigned to water and sanitation projects since 2006, when MAS took office nationally [69]. However, this is not a sizable investment compared to the general upward trend of the GDP (USD 33.94 billion in 2016 at time of the Finance Minister's statement) due to the rise in commodities exports [70]. Public spending is devoted to more visible and popular construction projects, for example bridges, paving roads, plazas, and soccer fields. For many in Cochabamba, this means large water and sewage infrastructure projects remain dependent upon external donors, making local control over water services vulnerable to their conditionalities. But for the water committees and cooperatives in the Southern Zone facing financial constraints, there is less direct support from international cooperation and greater reliance on funding allocated through government institutions, while the crisis of unequal access to water persists.

Despite abolishing the private contract and the strong anti-privatization sentiment that followed the Water War, water commodification is still present in Bolivia today, further undermining the establishment of a strong public participatory alternative. In fact, while the Constitution outlines that the state is responsible for guaranteeing access to water, it does make reference to mixed water providers, which could include a private profit seeking component [68]. Free market ideology is difficult to extinguish. The ongoing presence of the private sale of water in Cochabamba underscores the argument that the shift to "post-neoliberalism" is not categorical [71]. Private water sales are a 
product of the weaknesses of Cochabamba's public system, but they also provide a crutch for inaction on the part of government.

\section{Conclusions}

Social control and public participation were key components of MAS' 'process of change' that codified social control as a right and included direct citizen participation in the new Constitution. This paper posits that although these formal mechanisms were based on the claims for transformative participation that grew out of popular unrest, the mechanisms have resulted in nominal participatory practices that have served to work against meaningful change, de-radicalizing social movements in the process [55]. Similarly, the contradictions between official discourse and practice in the water governance reveal how formalized mechanisms of social control in the water sector have largely been rhetorical.

The complex case of the hard-fought public water services in Cochabamba illustrates the challenges of remunicipalization as the public state-led entity did not deliver on the expectation of social control in water management. As a result, some associate the remunicipalization process with the regression to procedural, inadequate and opaque government administration, and a kind of government intervention in the management of the water commons. This paper argues that from the outset, competing views of social control and participation have complicated the process of rebuilding SEMAPA after the failure of privatization. The focus here on participation reveals the political processes of decision-making among the various actors in the contested realm of water governance in Cochabamba. Water activists fighting for more progressive and equitable public water services faced resistance from powerful actors within the municipality and service provider eager to maintain influence within SEMAPA.

Public participation has been identified as a key principle of public alternatives to privatization. This paper has attempted to provide conceptual clarity to participation by creating a typology of reformative, transformative, and nominal participation. Adopting this lens of participation to analyze other instances of remunicipalization around the world could be a useful exercise to build a comparative guide, without negating local contexts. In turn, documenting cases where public participation has been more successfully integrated into models of water delivery, or other types of public services, could provide useful strategies for Cochabamba.

The contribution of the in-depth case study of remunicipalization, with input from multiple actors across the Bolivian water sector, can serve to inform the remunicipalization movement, and continue to push the discussion beyond anti-privatization debates. Understanding what leads to mixed results of remunicipalization is crucial to strengthening public alternatives [3]. Analyzing how water services have been rebuilt in a post-privatization context identifies the impediments and pathways towards building a successful public water provider.

Funding: This research was funded by a grant from the International Development Research Centre (107473-99906075-018).

Acknowledgments: I am grateful to David McDonald for his comments on this work. Thank you to the editors of this special issue. My gratitude extends to the scholars at the Centro AGUA and CESU-UMSS, in Cochabamba, Bolivia, in particular Rocío Bustamante, and Carlos Crespo, and to all the interviewees who participated in this research. Thank you to the anonymous reviewers of the article. Any shortcomings remain with the author.

Conflicts of Interest: The author declares no conflict of interest.

\section{References}

1. Kishimoto, S.; Petitjean, O. Reclaiming Public Services: How Cities and Citizens Are Turning Back Privatisation; Kishimoto, S., Petitjean, O., Eds.; Transnational Institute: Amsterdam, The Netherlands; Paris, France, 2017; ISBN 978-90-70563-58-5.

2. Lobina, E. Calling for progressive water policies. In Our Public Experience: The Global Experience with Remunicipalisation; Kishimoto, S., Lobina, E., Petitjean, O., Eds.; Transnational Institute: Amsterdam, The Netherlands, 2015; pp. 6-18. ISBN 978-90-7056-348-6. 
3. Del Ledo García, M.C. El Agua Nuestra de Cada día: Retos e Iniciativasde una Cochabamba Incluyente y Solidaria; CEPLAG-UMSS: Cochabamba, Bolivia, 2013.

4. McDonald, D.A. Remunicipalization: The future of water services? Geoforum 2018, 91, 47-56. [CrossRef]

5. McDonald, D.A.; Ruiters, G. Alternatives to Privatization: Public Options for Essential Services in the Global South; Routledge: London, UK, 2012; ISBN 978-0-203-14706-1.

6. Komadina, J.; Zegada, M.T. El Espejo de la Sociedad: Poder y Representación en Bolivia; Plural Editores: La Paz, Bolivia, 2014.

7. Hildyard, N.; Hegde, P.; Wolvekamp, P.; Reddy, S. Pluralism, Participation and Power: Joint Forest Management. In Participation: The new tyranny? Cooke, B., Kothari, U., Eds.; Zed Books: London, UK; New York, NY, USA, 2001; pp. 56-71.

8. Cohen, J.M.; Uphoff, N.T. Participation's place in rural development: Seeking clarity through specificity. World Dev. 1980, 8, 213-235. [CrossRef]

9. Stiefel, M.; Wolfe, M. A Voice for the Excluded: Popular Participation in Development-Utopia or Necesity; Zed Books: London, UK, 1994.

10. Henkel, H.; Stirrat, R.; Wolvekamp, P.; Reddy, S. Participation as Spiritual Duty; Empowerment as Secular Subjection. In Participation: The New Tyranny; Cooke, B., Kothari, U., Eds.; Zed Books: New York, NY, USA, 2001; pp. 168-182.

11. World Bank. World Bank PRSP Sourcebook; World Bank: Washington, DC, USA, 2000.

12. Chambers, R. Rural Development: Putting the Last First; Longman: London, UK, 1983; ISBN 978-0-582-64443-4.

13. Mohan, G.; Stokke, K. Participatory development and empowerment: The dangers of localism. Third World Q. 2000, 21, 247-268. [CrossRef]

14. Mansuri, G.; Rao, V. Localizing Development: Does Participation Work? Policy Research Report; World Bank: Washington, DC, USA, 2013.

15. Long, C. Participation of the Poor in Development Initiatives: Taking Their Rightful Places; Earthscan Publications: London, UK; Sterling, VA, USA, 2001; ISBN 978-1-85383-760-9.

16. White, S. Depoliticizing development: The uses and abuses of participation. In The Participation Reader; Cornwall, A., Ed.; Palgrave Macmillan: London, UK; New York, NY, USA, 2011; pp. 57-69. ISBN 978-1-84277-403-8.

17. Waddington, M.; Mohan, G. Failing forward: Going beyond PRA and imposed forms of participation. In Participation: From Tyranny to Transformation Exploring New Approaches to Participation in Development; Hickey, S., Mohan, G., Eds.; Palgrave Macmillan: London, UK; New York, NY, USA, 2004; pp. 219-234. ISBN 978-1-84277-460-1.

18. Cornwall, A. Whose Voices? Whose Choices? Reflections on Gender and Participatory Development. World Dev. 2003, 31, 1325-1342. [CrossRef]

19. Miraftab, F. Feminist Praxis, Citizenship and Informal Politics: Reflections on South Africa's Anti-Eviction Campaign. Int. Fem. J. Polit. 2006, 8, 194-218. [CrossRef]

20. Cooke, B.; Kothari, U. Participation: The New Tyranny; Cooke, B., Kothari, U., Eds.; Zed Books: New York, NY, USA, 2001; ISBN 978-1-85649-794-7.

21. Kesby, M. Retheorizing Empowerment-through-Participation as a Performance in Space: Beyond Tyranny to Transformation. Signs 2005, 30, 2037-2065. [CrossRef]

22. Green, M. Making Development Agents: Participation as Boundary Object in International Development. J. Dev. Stud. 2010, 46, 1240-1263. [CrossRef]

23. Leal, P.A. Participation: The ascendancy of a buzzword in the neo-liberal era. Dev. Pract. 2007, 17, 539-548. [CrossRef]

24. Hickey, S.; Mohan, G. Participation: From Tyranny to Transformation: Exploring New Approaches to Participation in Development; Hickey, S., Mohan, G., Eds.; Distributed Exclusively in the U.S. by Palgrave Macmillan; ZED Books: London, UK; New York, NY, USA, 2004; ISBN 978-1-84277-460-1.

25. Saxena, N.C. What is meant by people's participation? In The Participation Reader; Cornwall, A., Ed.; Palgrave Macmillan: London, UK; New York, NY, USA, 2011; pp. 31-33. ISBN 978-1-84277-403-8.

26. Perreault, T. Performing Participation: Mining, Power, and the Limits of Public Consultation in Bolivia. J. Lat. Am. Caribb. Anthropol. 2015, 20, 433-451. [CrossRef] 
27. Brown, D. Participation in poverty reduction strategies: Democracy strenghtened or democracy undermined? In Participation: From Tyranny to Transformation: Exploring New Approaches to Participation in Development; Hickey, S., Mohan, G., Eds.; Palgrave Macmillan: London, UK; New York, NY, USA, 2004; pp. 237-250. ISBN 978-1-84277-460-1.

28. Cornwall, A. Making Spaces, Changing Places: Situating Participation in Development; IDS Working Paper; Institute of Development Studies: Brighton, UK, 2002.

29. Arnstein, S.R. A Ladder of Citizen Participation. J. Am. Inst. Plann. 1969, 35, 216-224. [CrossRef]

30. McNeish, J.-A. Extraction, Protest and Indigeneity in Bolivia: The TIPNIS Effect. Lat. Am. Caribb. Ethn. Stud. 2013, 8, 221-242. [CrossRef]

31. Aguilar Miranda, L.A.; Miranda Hernández, M.A. Democracia Participativa: ¿Realidad o Espejismo; Gandarillas Gonzáes, M.A., Ed.; CEDIB: Cochabamba, Bolivia, 2012.

32. Cielo, C. Aprendizajes desde el periurbano boliviano. Villa Libre Cuad. Estud. Soc. Urbanos 2009, 4, 7-35.

33. Kohl, B.H.; Farthing, L. Impasse in Bolivia: Neoliberal Hegemony and Popular Resistance; Zed Books: London, UK; New York, NY, USA, 2006; ISBN 978-1-84277-758-9.

34. Goldman, M. How “'Water for All!'” policy became hegemonic: The power of the World Bank and its transnational policy networks. Geoforum 2007, 38, 786-800. [CrossRef]

35. Dangl, B. The Price of Fire: Resource Wars and Social Movements in Bolivia; AK Press: Edinburgh, UK, 2007; ISBN 978-1-904859-33-8.

36. Ahlers, R. Empowering or Disempowering: The Gender Dimensions of Neoliberal Water Policy in Mexico and Bolivia. In Opposing Currents: The Politics of Water and Gender in Latin America; Bennett, V., Dávila-Poblete, S., Rico, M.N., Eds.; University of Pittsburgh Press: Pittsburgh, PA, USA, 2005; pp. 53-71. ISBN 978-0-8229-5854-3.

37. Assies, W. David versus Goliath in Cochabamba. Lat. Am. Perspect. 2003, 30, 14-36. [CrossRef]

38. Bustamante, R.; Peredo, E.; Udaeta, M.E. Women in the "Water War" in the Cochabamba Valleys. In Opposing Currents: The Politics of Water and Gender in Latin America; Bennett, V., Dávila-Poblete, S., Rico, M.N., Eds.; University of Pittsburgh Press: Pittsburgh, PA, USA, 2005; ISBN 978-0-8229-5854-3.

39. Olivera, O.; Lewis, T. !Cochabamba!: Water War in Bolivia. South End Press: Cambridge, MA, USA, 2004.

40. Crespo, C.; Peredo, C.; Fernández, O. Los Regantes de Cochabamba en la Guerra del Agua:Presión Social y Negociación.; CESU-UMSS: Cochabamba, Bolivia, 2004.

41. Shultz, J. The Cochabamba Water Revolt and Its Aftermath. In Dignity and Defiance: Stories from Bolivia's Challenge to Globalization; Draper, M.C., Shultz, J., Eds.; University of California Press: Berkeley, CA, USA; London, UK, 2008; pp. 9-43.

42. Laurie, N. Gender Water Networks: Femininity and Masculinity in Water Politics in Bolivia. Int. J. Urban Reg. Res. 2011, 35, 172-188. [CrossRef]

43. Garande, T.; Dagg, S. Public Participation and Effective Water Governance at the Local Level: A Case Study from a Small Under-Developed Area in Chile. Environ. Dev. Sustain. 2005, 7, 417-431. [CrossRef]

44. Michener, V.J. The Participatory Approach: Contradiction and Co-option in Burkina Faso. World Dev. 1998, 26, 2105-2118. [CrossRef]

45. Bustamante, R.; Gutiérrez, Z. Usos y costumbres en la gestion de riego: Caos u orden en la gestión de agua para riego. In Aguas y Municipios: Retos para la Gestión Municipal de agua para Riego; Hoogendam, P., Ed.; PEIRAV, Plural Editores: La Paz, Bolivia, 1999; pp. 163-188.

46. Lazar, S. El Alto, Rebel City: Self and Citizenship in Andean Bolivia; Mignolo, W.D., Silverblatt, I., Saldívar-Hull, S., Eds.; Duke University Press: Durham, NC, USA, 2007; ISBN 978-0-8223-8876-0.

47. Cleaver, F. Institutions, Agency, and the Limmitation of Participatory Approaches to Development. In Participation: The New Tyranny; Cooke, B., Kothari, U., Eds.; Zed Books: London, UK, 2001.

48. Sánchez Gómez, L.; Terhorst, P. Cochabamba, Bolivia: Public-collective partnerships after the Water War. In Reclaiming Public Water: Achievements, Struggles, and Visions from Around the World; Balanya, B., Hoedeman, K., Terhorst, P., Eds.; TNI: Amsterdam, The Netherlands, 2005; pp. 121-130.

49. Crespo, C.F.; Fernández, O. Estado, Movimientos Sociales y Recursos Hidricos. Presión Social y Negociación Luego de la Guerra del agua de Cochabamba; CESU-UMSS: Cochabamba, Bolivia, 2004.

50. Wainwright, H. Transformative resistance: The role of labour and trade unions in alternatives to privatization. In Alternatives to Privatization: Public Options for Essential Services in the Global South; McDonald, D.A., Ruiters, G., Eds.; HSRC Press: Cape Town, South Africa; pp. 71-98. 
51. Crespo, C.F. La ley de Riego y sus Reglamentos: Riesgos y Desafios; Todo sobre el agua; Comisión para la Gestión Integral del Agua en Bolivia (CGIAB): Cochabamba, Bolivia, 2006.

52. Driessen, T. Collective management strategies and elite resistance in Cochabamba, Bolivia. Development 2008, 51, 89-95. [CrossRef]

53. Spronk, S. Roots of Resistance to Urban Water Privatization in Bolivia: The "New Working Class," the crisis of neoliberalism, and public services. Int. Labor Work. Class Hist. 2007, 71, 8-28. [CrossRef]

54. Postero, N. Morales's MAS Government. Lat. Am. Perspect. 2010, 37, 18-34. [CrossRef]

55. MMAyA. Plan Nacional de Desarollo del Riego para "Vivir Bien": 2007-2011; Ministerio del Agua, Viceministerio de Riego: La Paz, Bolivia, 2007.

56. Estado Plurinacional de Bolivia (EPB). Nueva Constitución Politica del Estado; UPS: La Paz, Bolivia, 2009.

57. Boelens, R. Water Rights Arenas in the Andes: Upscaling Networks to Strengthen Local Water Control. Water Altern. 2008, 1, 48-65.

58. Bakker, K.J. Privatizing Water: Governance Failure and the World's Urban Water Crisis; Cornell University Press: Ithaca, NY, USA, 2010; ISBN 978-0-8014-4723-5.

59. Marston, A.J. The Scale of Informality: Community-Run Water Systems in Peri-Urban Cochabamba, Bolivia. Water Altern. 2014, 7, 72-88.

60. Perreault, T. Custom and Contradiction: Rural Water Governance and the Politics of Usos y Costumbres in Bolivia's Irrigators' Movement. Ann. Assoc. Am. Geogr. 2008, 98, 834-854. [CrossRef]

61. Seemann, M. Inclusive recognition politics and the struggle over hydrosocial territories in two Bolivian highland communities. Water Int. 2016, 41, 157-172. [CrossRef]

62. Instituto Nacioal de Estadistica. Bolivia. Available online: https://www.ine.gob.bo/ (accessed on 4 January 2018).

63. Campanini, O. Agua y saneamiento: Elementos de análisis de la actual política (Parte I). Petropress 2014, 33, 48-56.

64. Regalsky, P. Political Processes and the Reconfiguration of the State in Bolivia. Lat. Am. Perspect. 2010, 37, 35-50. [CrossRef]

65. Grandydier, F; Tinta, R. Experiencia de la asociación de sistemas comunitarios de agua potbale de la zona Sur del municipio de Cochabamba. In Apoyo a la Gestión de Comités de agua Potable: Experiencias de Fortalecimiento a Comités de agua Potable Comunitarios en Bolivia y Colombia; Quiroz, F., Faysse, N., Ampuero, R., Eds.; Centro AGUA-UMSS: Cochabamba, Bolivia, 2006; pp. 239-258.

66. Achtenberg, E. Morales Greenlights TIPNIS Road, Oil and Gas Extraction in Bolivia's National Parks, NACLA Rebel Curr. 2015. Available online: https://nacla.org/blog/2015/06/15/morales-greenlights-tipnis-road-oiland-gas-extraction-bolivia\%E2\%80\%99s-national-parks (accessed on 10 July 2019).

67. Ruiz, C. Bolivian Vice President García Linera vs. NGOs: A Look at the Debate. Available online: http://upsidedownworld.org/archives/bolivia/bolivian-vice-president-garcia-linera-vs-ngos-a-lookat-the-debate/ (accessed on 14 March 2018).

68. Spronk, S. Post-Neoliberalism in Latin America? Urban Water Supply Management in Bolivia under Evo Morales. In Proceedings of the Townhouse Hotel and Conference Centre, Cape Town, South Africa, 13-16 April 2014.

69. Gobierno Asegura que Desde 2006 Invirtió Bs 8.417 Millones en Proyectos de agua. Los Tiempo Digit. 2016. Available online: https:/www.lostiempos.com/actualidad/nacional/20161117/gobierno-asegura-que-2006invirtio-bs-8417-millones-proyectos-agua (accessed on 10 July 2019).

70. Bolivia, GDP (Current US\$). Available online: https://data.worldbank.org/country/bolivia (accessed on 26 December 2018).

71. Webber, J.R. From Rebellion to Reform in Bolivia: Class. Struggle, Indigenous Liberation, and the Politics of Evo Morales; Haymarket Books: Chicago, IL, USA, 2011; ISBN 978-1-60846-106-6.

(C) 2019 by the author. Licensee MDPI, Basel, Switzerland. This article is an open access article distributed under the terms and conditions of the Creative Commons Attribution (CC BY) license (http://creativecommons.org/licenses/by/4.0/). 